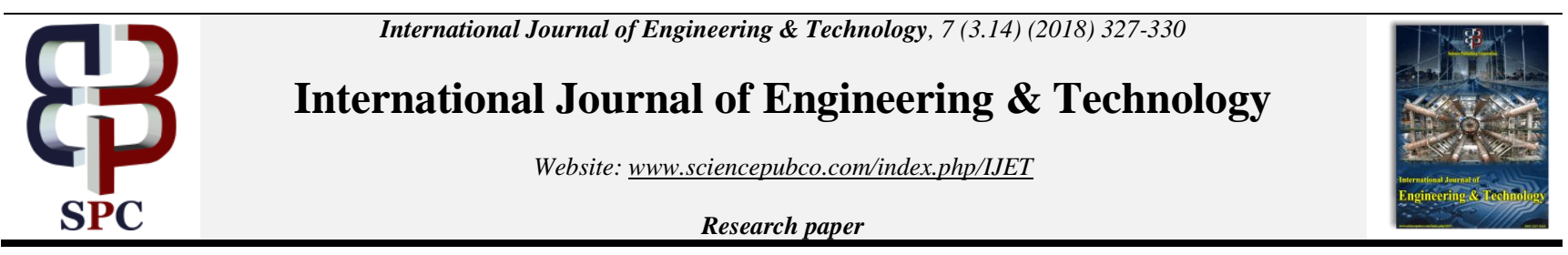

\title{
Psychological Factors for Computer Game Addiction of Young Adolescents
}

\author{
Anna Viktorovna Grishina ${ }^{1}$, Elena Nikolaevna Volkova ${ }^{1}$

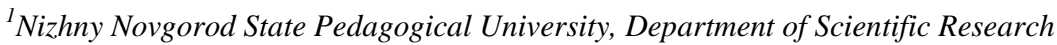 \\ Ulyanova St., 1, Nizhny Novgorod, 603002, Russia \\ ${ }^{2}$ Saint Petersburg State University, Department of Psychology \\ Universitetskaya Emb., 13B, St Petersburg, 199034, Russia
}

\begin{abstract}
consider the psychological features regarding the development of younger adolescents, the violation of which may be the cause of computer game addiction at a given age stage of development.

The issue of the influence of computer game addiction on the mental and personal development of a younger adolescent has not been studied enough. An analysis of psychological studies has shown that the psychological factors, conditions and mechanisms that determine the characteristics of computer game addiction in early adolescence are not adequately worked out.

In this study, a theoretical analysis of personal prerequisites for the development of computer game addiction in younger adolescents was conducted, which allowed determining that computer game addiction arose from a combination of two groups of factors: personal and socio-psychological.

The personal factors of computer game addiction in younger adolescents were revealed: inadequate, often overestimated self-esteem, increased desire for risk and search for acute sensations, weak volitional potential, unbalanced development of a child's agency. The socio-psychological factors of computer game addiction in eatly adolescence were revealed, which were a combination of the features of child-parent relations and the characteristics of the child's interaction with peers.
\end{abstract}

Keywords: Adolescent, early adolescence, game, computer, addiction, questionnaire, computer game addiction, factors of computer game addiction.

\section{Introduction}

This document can be used as in continuous developments in the A lot of scientific research has been devoted to the study of the specifics of the interaction of children and adolescents with computers (O.N. Arestova, L.N. Babanin, Yu.D. Babayeva, A.E. Voiskunsky, S.A. Shapkin, M. Cole et al.). However, in our opinion, the issue of the psychological factors of computer game addiction at different stages of ontogeny, in particular of adolescence, remained without proper attention.

Despite the generality of the basic psychological characteristics of the general adolescent period, each stage of adolescence has its own psychological characteristics [1-3, 13-14]. In our opinion, the issue of computer game addiction at the stage of early adolescence, as the initial stage of the general adolescence period of development, becomes more and more relevant.

Computer game addiction is widespread worldwide and in Russia in particular $[4,10]$. Now computer games are becoming available to different population stratum and involve people of different age (from adolescents to seniors), wealth status, social network, ethnicity, etc [7]. This fact is explained by the widest variety of types and forms of computer games, designed for different categories of people with different levels of income and interests. In addition, everyone can play computer games, since in the majority they do not require special skills $[6,9,11]$.
The goal of this paper is to identify psychological factors that can contribute to the formation of computer game addiction in early adolescence.

We assume that the psychological characteristics and personality traits of younger adolescents with a pathological addiction toward computer games differ significantly from those of younger adolescents who do not show such an addiction.

During the study, we applied the following methods: theoretical methods (an analysis of psychological and educational literature); empirical methods (observation, questioning, surveys, tests); statistical result processing methods using the analysis package in MS Excel and STATISTICA.

Analyzing the contemporary approaches to the study of psychological factors of the computer addiction $[5,8,12,15]$, and considering the psychological features of early adolescence, we identified psychological factors that could possibly contribute to computer game addiction at a given age stage of development:

1. The personal factors: mental abilities; self-esteem; communicative abilities; risk appetite; agency; anxiety; volitional potential; sex.

2. The factors of social environment: child-parent relations (neglect of parents of their duties, frequent purchases of computer games); relations with classmates (status and place in the group); social network outside the school. 


\section{Methods}

The methodological basis of the study is the philosophical aspects of a person as an active agent, who knows and transforms the world and him or herself in the process of activity (S.L. Rubinshtein, M.Ya. Basov, L.A. Wenger, I.S. Kon, G.G. Granatov et al.); the provisions of philosophical and axiological theories that view a child as the highest value and an end in itself of social development (L. Vygotsky, A.V. Zaporozhets, V.S. Mukhina, A.G. Asmolov, A.N. Leontiev, A.V. Petrovsky, A.G. Gostev et al.); the provisions of Russian psychology about the causes of addictive behavior (V.Yu. Zavyalov, V.Ya. Semke, N.A. Bokhan, A.I. Mandel, Ts.P. Korolenko, N.L. Bochkareva, T.A. Donskikh, E.P. Ilyin); the concept of psychological Internet addiction (K. Young); the concept of agency (E.N. Volkova).

The theoretical basis of the study is determined by general psychological theories of adolescence (L.S. Vygotsky, A.N. Leontiev, V.V. Davidov, A.V. Petrovsky, D.B. Elkonin et al.); the methodological papers of Russian and foreign authors on the issues of computer game addiction had an essential value for this thesis paper: a study of the psychological causes of computer game addiction (Yu.V. Fomichev, A.G. Shmelev, I.V. Burmistrov), an analysis of factors of personal predisposition to computer game addiction, as well as psychological consequences of computer game addiction for the individual (O.N. Arestova, L.N. Babanin, Yu.D. Babaeva, A.E. Voiskunsky, A.V. Khudyakov, Yu.V. Staroverova, M.S. Kiseleva, M. Cole, K. Young, I.V. Burlakov, M.S. Ivanov, G.M. Avilov, O.K. Tikhomirov, S. Bodker, I.G. Belavina, N.A. Sadovskaya, V.D. Gorsky, S.A. Shapkin, E.E. Lisenko, D. Greenfield, K. Surratt, O.V. Doronin, A.O. Prokhorov, A.E. Serezhkina, A.N. Mokhovikov, L.P. Guriev et al.). Mental abilities were studied using a standardized CF-2 test "Cattell Culture Fair Intelligence Test". Self-esteem was studied using the DemboRubinstein method. Communicative abilities were studied using the Communicative and Organizational Propensities (COP) tech- nique. Risk appetite was studied using the SR-2 Risk Appetite Questionnaire. Agency was studied using the Agency Indicators Questionnaire developed and adapted for young adolescents. Anxiety was detected using the Anxiety Test (Spielberger-Hanin test). A diagnosis of volitional personality potential was carried out using the test of A.V. Zverkov and E.V. Eidman. The degree of passion for computer games was revealed with the help of our test "The Degree of Computer Game Passion".

The features of communication of younger adolescents with parents were investigated using the author's questionnaire on the identification of relations in the family. The features of communication with classmates were identified using sociometry of the Moreno technique. The features of communication outside the school were determined using the questionnaire for external referentometry.

The study involved 146 students from 5th-6th grades of secondary schools in Nizhny Novgorod; 76 of them were boys and 71 were girls of 10 to 12 years old.

At the first stage of the study, based on the results of a questionnaire designed to determine the degree of computer game passion, the younger adolescents were divided into two groups: the first group included younger adolescents with a high degree of computer game passion, and the second group had a low degree of computer game passion.

\section{Results}

A comparative analysis of the results showed that the personal and social factors were different for the adolescents of two groups.

Table 1 presents the results of the personality factors of adolescents: mental abilities, self-esteem, risk appetite, agency indicators, anxiety and volitional self-regulation.

Table 1. Personal Factors

\begin{tabular}{|c|c|c|c|}
\hline Personal factors & Average value, $\mathrm{M}+\mathrm{Q}$ & Average value, $\mathrm{M}+\mathrm{Q}$ & Differences significance \\
\hline Passion & High & Low & \\
\hline Mental abilities & $87.83 * *+16.24$ & $93.73^{* *+14.89}$ & Significant, $\mathrm{p}<0.01(* *)$ \\
\hline \multicolumn{4}{|l|}{ Self-esteem } \\
\hline Confident & $70.61 * * \pm 22.83$ & $62.65^{* *} \pm 16.11$ & Significant, $\mathrm{p}<0.01(* *)$ \\
\hline Communicative & $48.818 * * *+29.399$ & $70.754 * * * \pm 23.235$ & Significant, $\mathrm{p}<0.01(* *)$ \\
\hline Communicative abilities & $0.7 * \pm 0.2$ & $0.8^{*} \pm 0.2$ & $\mathrm{p}<0.5(*)$ \\
\hline Risk appetite & $8.861 * * * \pm 1.945$ & $7.486 * * * \pm 1.777$ & Significant, $\mathrm{p}<0.01(* *)$ \\
\hline \multicolumn{4}{|l|}{ Agency } \\
\hline Free to choose and responsibility & $2.34 * * \pm 0.94$ & $2.70^{* * \pm 0.75}$ & Significant, $\mathrm{p}<0.01(* *)$ \\
\hline Awareness of one's own uniqueness & $2.97 * * \pm 1.16$ & $3.36 * * \pm 0.95$ & Significant, $\mathrm{p}<0.01(* *)$ \\
\hline Understanding and acceptance of another & $2.110 * * * \pm 0.737$ & $2.616 * * * \pm 0.576$ & Significant, $\mathrm{p}<0.01(* *)$ \\
\hline \multicolumn{4}{|l|}{ Anxiety } \\
\hline Trait anxiety & $42.1 * \pm 7.9$ & $39.8 * \pm 6.9$ & $\mathrm{p}<0.5(*)$ \\
\hline State anxiety & $23.2 * \pm 6.8$ & $23.0 * \pm 8.5$ & $\mathrm{p}<0.5(*)$ \\
\hline Volitional self-regulation & $8.50^{* *} \pm 2.81$ & $9.70 * * \pm 2.42$ & Significant, $\mathrm{p}<0.01(* *)$ \\
\hline Sex & $66.243^{* * *} \pm 16.919$ & $51.875^{* * * \pm 17.307}$ & Significant, $\mathrm{p}<0.01(* *)$ \\
\hline
\end{tabular}

$p<0.5(*) ; p<0.01(* *) ; p<0.001(* * *)$

The results show that the younger adolescents with a high degree of computer game passion have lower mental abilities $(\mathrm{M}+\mathrm{Q}=$ $87.83+16.24, \mathrm{p}<0.01)$ than their peers $(\mathrm{M} \pm \mathrm{Q}=93.73 * *+14.89$, $\mathrm{p}<0.01)$. Perhaps this is due to the fact that unlike real games with peers, computer games are more destructive for the full development of a younger adolescent. The computer games developed for a given (predictable, one-type) script cannot fully reflect the life situations, simplify the ways to solve various problems, do not contain moral problems, and thus contribute to the primitivization of thinking.

Computer games have an impact on an adolescent's self-esteem development. They provoke the growth of inflated inadequate self-esteem in a child's soul, since the entire virtual world of the computer games is programmed and focused on the player, indulging all his actions and manipulations. This orientation leads to the development of selfishness, which is expressed in the inadequate consciousness attitude that everything must revolve around him or her.

We examined the self-esteem indicators by Confident, Capable, Happy, Sociable, Hardworking, Wise criteria. In the study of selfesteem, it was found that younger adolescents with a high degree of computer gaming were more confident and less sociable.

Divergences in the level of intelligence of a young adolescent with his or her self-esteem may indicate an inadequate attitude towards 
him or herself as a result of the incongruence of "I Real" and "I Virtual."

During the game, the psyche of the younger adolescent forms its own virtual world, which has a certain degree of stability. The game reality acts as a kind of transformer of a child's consciousness. In this case, emotions are concentrated around a computer game player and his or her actions. The changed state of consciousness is sensitive to the slightest changes in the playing space. The victories of the virtual character are perceived as personal achievements; the child feels him- or herself as a hero. The victory is positive self-esteem and positive emotions. The game becomes the environment for the formation of personal features, an indicator of success. Adolescents who do not pass role identification in social reality find their image in the game.

The analysis of communicative abilities has shown that the level of differences between two selected groups is not significant. The obtained data contradict the criteria of asociality. Perhaps the normative manifestation of communicative skills is due to the fact that younger adolescents, who often play computer games, rather actively interact with each other; they are grouped together. They share their achievements and successes. They actively discuss new computer games. Such groups have their own terminology and concepts.

The prevalence of risk appetite in younger adolescents with a high degree of computer gaming is revealed, compared with younger adolescents with a low degree of it.

The game is the most common form of spending leisure time. The motivation of a computer player is based on the principle "an instant response to an instant request". A computer game allows a child to experience extraordinary excitement, a sense of selfsuccess, importance, a feeling of having been chosen (I'm special, I'm better than others!).

If the younger adolescent does not receive such emotions in real life, he or she will strive to meet them over and over again in computer game. Delight from obtaining the desired result and excitement from his or her expectations become more attractive than all the other joys of life. The child begins to devote more and more time to computer games; he or she constantly thinks, reflects on them. He or she increasingly strives to play and become more risky at the same time.

The adolescents with a high degree of computer gaming passion have a steady need for the game; but at the same time they cannot completely satisfy it, they are in a state of frustration, although they have the ability to satisfy the need [10]. The key to understanding this paradox can be the division of the psychic reality of addicts into a virtual world and a real world $[1,9]$.

The children with a high degree of computer gaming passion have low rates for such parameters of agency as Free to Choose and Responsibility, Awareness of One's Own Uniqueness, Understanding and Acceptance of Another. This is probably due to the fact that the player's attitude to the characters of the virtual world is transferred to the outside world. The real people in the mind of the child become objects that can be manipulated as computer characters at their own discretion; they do not take into account their interests, opinions, desires.

The level of difference betwee the indicators of anxiety in the selected groups is not significant. The volitional parameters in younger adolescents of the first group are much lower than in the second group.

Having determined the degree of computer gaming passion in boys and girls, we have revealed very characteristic differences between them. The results show that the boys are more likely to play computer games than girls.

Table 2 presents the results of social environment factors: childparent relations, relationships with classmates, attitudes toward meaningful people outside the school.

Table 2. Social environment factors

\begin{tabular}{|c|c|c|c|}
\hline Social environment factors & Average value, $\mathrm{M} \pm \mathrm{Q}$ & Average value, $\mathrm{M}+\mathrm{Q}$ & Differences significance \\
\hline Passion & High & Low & \\
\hline \multicolumn{4}{|l|}{ Child-parent relations } \\
\hline Pamper by buying a lot of games & $53.89^{* *} \pm 32.83$ & $40.54 * * \pm 23.63$ & Significant, $\mathrm{p}<0.01(* *)$ \\
\hline \multicolumn{4}{|l|}{ Relations with classmates } \\
\hline Status & $0.32 * * \pm 0.17$ & $0.24 * * \pm 0.13$ & Significant, $\mathrm{p}<0.01(* *)$ \\
\hline \multicolumn{4}{|l|}{ Attitude towards meaningful people outside the school } \\
\hline Relatives (grandfather, grandmother, uncle, aunt) & $0.833 * * *+1.267$ & $2.392 * * * \pm 1.620$ & Significant, $\mathrm{p}<0.01(* *)$ \\
\hline Friends & $3.06 * * \pm 1.61$ & $2.26 * *+1.51$ & Significant, $\mathrm{p}<0.01(* *)$ \\
\hline A known person & $0.03 * * \pm 0.17$ & $0.16^{* *} \pm 0.55$ & Significant, $\mathrm{p}<0.01(* *)$ \\
\hline A computer game character & $0.750 * * *+1.219$ & $0.162 * * * \pm 0.439$ & Significant, $\mathrm{p}<0.01(* *)$ \\
\hline A book character & $0.01 * * \pm 0.01$ & $0.11^{* *} \pm 0.31$ & Significant, $\mathrm{p}<0.01(* *)$ \\
\hline
\end{tabular}

$p<0.5(*) ; p<0.01(* *) ; p<0.001(* * *$

The formation of groups (finding a friend, searching for someone who can understand you) is a typical feature of a younger adolescent.

The social network among younger adolescents with a high degree of computer gaming passion is smaller; mostly it comes down to communicating with friends and characters of computer games. Low rates were obtained in communication with relatives and book characters. Based on this, it can be assumed that the younger adolescents spend little time on reading. The entire leisure time of these children basically comes down to playing computer. A computer game opens before a child a new world of innumerable opportunities and interests, "cuts off" him or her from the real world and "switches" to itself. On the basis of the results, it is possible to single out the reasons for the increased passion of younger adolescents to computer games.
These include problems associated with communication (a computer game character acts as a "friend" for an addicted person, virtual communication is preferable to the real one); problems of personal self-assertion (self-esteem, achievement of status and authority among peers).

A computer game serves as a means to meet those needs of a younger adolescent, which are not satisfied in real life, a means of compensating for life's problems. The personality begins to be realized in the illusory gaming world, and not in the real world; this entails a number of serious problems in the development of the personality, in the formation of self-consciousness and selfesteem, as well as in the higher spheres of the personality structure. 


\section{Conclusion}

A computer game is an affordable way of modeling another world, life situations. This is a way to stay in the world without life's problems and hassle. The psychological aspects of the mechanism are based on the natural desire of a person to get rid of various problems and troubles related to daily life. Abuse of this way of escape from reality and loss of control of involvement in this type of activity can lead to the emergence of a danger not of a temporary but complete detachment from reality, and as a result, the formation of a very strong psychological computer game addiction.

Given such age features of younger adolescents as weak volitional self-regulation, it becomes obvious that computer games provoke children to systematically avoid doing homework, as well as school lessons. As a consequence, a psychological separation of the child from the school is possible with all the ensuing consequences.

The problem of preventing computer game addiction in younger adolescents is now particularly important, as a modern child grows up and develops in a tense social environment. The life of junior adolescents is filled with various emotions connected with difficulties in relations with parents or the family's unhappiness, the influence of the youth subculture, the media, the lack of material wealth in the family, etc. Consequently, the child organizes his or her free time in connection with his or her interests, needs and opportunities. Thus, the objective of psychologists is to develop a psycho-pedagogical program, the goal of which is to prevent pathological computer game addiction, as well as direct the activity of younger adolescents and the development of the surrounding world of the child into a positive meaningful activity, and also, if possible, to minimize negative social impacts associated with the computer games.

\section{Acknowledgements}

The study was conducted with the support of the Ministry of Education and Science of the Russian Federation in the framework of performing the government papers in the field of scientific activity (the basic part of Givernment Task No. 25.5107.2017/BCh, 20172019). The Project Topic: "The estimation of the prevalence of computer game addiction and the study of the degree of stress in young adolescents", E.N. Volkova, Doctor of Psychology, Professor.

\section{References}

[1] G.I. Alaverdashvili. Semya, shkola, podrostok [Family, School, Adolescent]. Tbilisi: Ministry of Education of the GSSR, 1986, pp. 65.

[2] V.A. Averin. Psihologiya detej i podrostkov [Psychology of children and adolescents]. St. Petersburg, 1998, pp. 379.

[3] V.G. Bobrova. Obshchaya harakteristika razvitiya lichnosti podrostka (iz kursa lekcij po psihologii) [General characteristics of the teenager personality development (from the course of lectures on psychology)]. Rostov-on-Don, 1966, pp. 23.

[4] Yu.V. Fomicheva, A.G. Shmelev, I.V. Burmistrov. Psihologicheskie korrelyaty uvlechennosti komp'yuternymi igrami [Psychological correlates of passion for computer games]. Bulletin of the Moscow State University, Psychology, 14(3), 1991.

[5] I. Goldberg. Internet addiction. 1995. Available online: http://www.psycom.net/iasg.html

[6] M.S. Ivanov. Psihologicheskie aspekty negativnogo vliyaniya igrovoj komp'yuternoj zavisimosti na lichnost' cheloveka [Psychological aspects of the negative impact of computer game addiction on the person]. Psychological Journal, 20(1), 1999, pp. 94-102.
[7] S.A. Shapkin. Komp'yuternaya igra: novaya oblast' psihologicheskih issledovanij [Computer game: A new area of psychological research]. Psychological Journal, 20(1), 1999, pp. 86-102.

[8] M.A. Shotton. Computer Addiction? A study of computer dependency. J. Affective Disorders, 5, 1998, pp. 56-59.

[9] T.D. Sterledeva. Mir cheloveka v virtualnoi realnosti [The World of a Person in Virtual Reality]. Perm: Publishing House of Perm State University, 2003, pp. 344.

[10] O.K. Tikhomirov, L.N. Babanin. EHVM i novye problemy psihologii [Computers and new psychological problems]. Moscow, Moscow State University, 1986, pp. 203.

[11] V.G. Titov. Igra v zhizn': razmyshleniya o virtual'noj real'nost [Game of life: Reflections on virtual reality]. Moscow, Metochion of the Holy Trinity Sergius Lavra, 1998.

[12] Sh. Turkle. Constructions and reconstructions of the self in virtual Reality. Massachusetts Institute of Technology. The Internet Identity Workshop, 1997.

[13] N.V. Vanyukhina. Osobennosti psikhicheskikh sostoyanii detei podrostkovogo vozrasta: Ph.D. (Phycological Sciences) [Features of Mental States of Adolescents (Ph.D. Thesis)]. Moscow, 1988, pp 20

[14] L.S. Vygotsky. Pedologiya podrostka [The pedology of the adolescent]. Moscow, Col. Works, 4, 1984, pp. 326.

[15] K. Young. Caught in the Net. New York: John Wiley and Sons, 1996, pp. 311. 